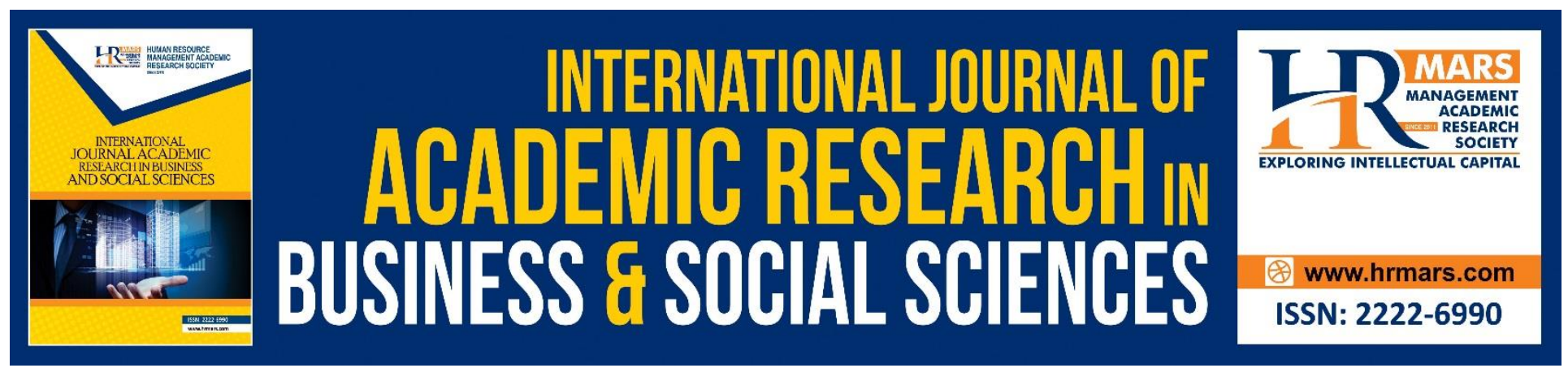

\title{
The Factors Influencing the Level of Well-being among Elderly in Selangor, Malaysia
}

Umi Abidah Noor Osman, Ramlee Ismail

To Link this Article: http://dx.doi.org/10.6007/IJARBSS/v9-i3/5668

DOI: $\quad 10.6007 /$ IJARBSS/v9-i3/5668

Received: 30 Jan 2019, Revised: 24 Feb 2019, Accepted: 04 March 2019

Published Online: 08 March 2019

In-Text Citation: (Osman \& Ismail, 2019)

To Cite this Article: Osman, U. A. N., \& Ismail, R. (2019). The Factors Influencing the Level of Well-being among Elderly in Selangor, Malaysia. International Journal of Academic Research in Business and Social Sciences, 9(2), 1108-1120.

Copyright: @ 2019 The Author(s)

Published by Human Resource Management Academic Research Society (www.hrmars.com)

This article is published under the Creative Commons Attribution (CC BY 4.0) license. Anyone may reproduce, distribute, translate and create derivative works of this article (for both commercial and non-commercial purposes), subject to full attribution to the original publication and authors. The full terms of this license may be seen at: $\underline{\text { http://creativecommons.org/licences/by/4.0/legalcode }}$

\section{Vol. 9, No. 3, 2019, Pg. 1108 - 1120}




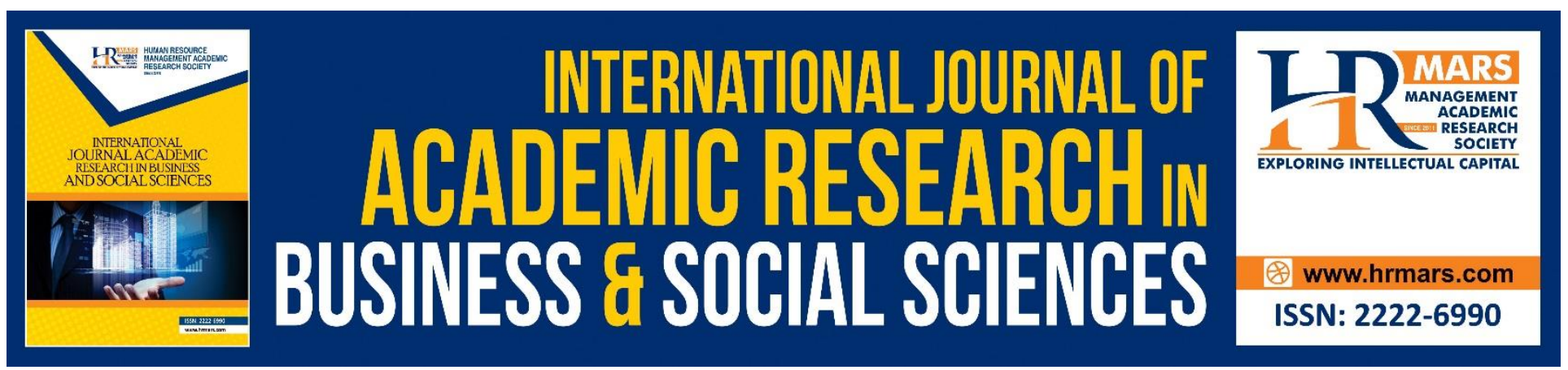

\title{
The Factors Influencing the Level of Well-being among Elderly in Selangor, Malaysia
}

\author{
Umi Abidah Noor Osman, Ramlee Ismail \\ Faculty of Management and Economic, Universiti Pendidikan Sultan Idris, 35900 Tanjong Malim \\ Perak, Malaysia
}

\section{Abstract}

Increasing in ageing population has drawn attention to the level of well-being among elderly. This study measures the level of well-being among elderly in Selangor. Furthermore, this study conducted to determine how far the factors influencing the well-being. The research factors namely personal factor, social participation, financial factor, neighbourhood and the level of income. A survey method was conducted to collect data. This study used a sample of 466 respondents living in rural areas and urban areas. In order to examine the differences between the living areas namely rural and urban areas on the well-being among elderly in Selangor, t- test analysis was used to access the statistical significant differences. Then, a regression analysis was performed to measure the influence of personal factor, social participation, financial factor, neighbourhood and level of income on their level of well-being. The findings suggested that all the factors had influenced the level of prosperity among elderly. However, income factor was not an essential factor in the welfare of older. Therefore, the implication of this study suggested that elderly must be provided with their personal and social needs to increase their level of well-being.

Keywords: Personal factor, Social Participation, Financial factor, Level of income, Well-being

\section{Introduction}

The changes in the trend of population had influenced by the economic growth and development. Today, the trend of population shows the increasing in older people. This happened due to rising life expectancy and declining fertility rate. The declining in rising life expectancy and declining fertility rates resulting from a higher level of education, advanced technology and economic control. Developing countries especially will be experiencing the rapid transition of the population trend. As a result, the increasing in ageing population have effect on economic growth globally, workforces, saving, pensions investment, living condition, consumption, and taxes.

In Malaysia, the changing in population trend issue not very critical, as the country has not become an ageing nation yet. However, reported that population growth rapidly in Malaysia can have consequences for an individual's income, health and education and might as well as well-being. 
In a meantime, Malaysia faces several issues including rising cost of living, rising consumer inflation, rising debt, stringent credit terms, and a slowdown in economic activity. All of these situations affect the quality of life of the population in this country. Malaysia has used the Malaysian Well-being Index (MWI) (EPU, 2013) to measure the level of well-being and quality of life of the country. Well-being in the MWI refers to the physical, social and economic benefits that contribute to the improvement of the quality of life and the satisfaction of individuals, families and communities (Malaysia's Well-being Index Report, 2013). However, there are no specific factors to measure the level of well-being among elderly in Malaysia.

\section{Literature Review}

\section{Elderly}

Elderly or older people refers to the individual with the age of 60 years old and above which have been mentioned in the United Nation World Assembly on Ageing in Vienna (United Nations, 1983). As well as in Malaysia, The National Policy on Senior Citizens defined elderly as those who are above the age of 60 years old (Bahagian Pasca Perkhidmatan, 2015).

\section{Well-being}

The research objective of this study is to measure the factors influence the well-being among elderly. Personal factor, social participation, financial factor, neighborhood were taking into account to measure their influence on the level of well-being among elderly in Selangor.

The well-being by (OECD, 2013) has yet no specific definition. The well-being is interchangeably used with the quality of life, happiness and life satisfaction. While, well-being by Diener, Oishi, and Lucas (2015) and Sarracino (2010) refers to the perspective or evaluation of people on their own experience. The evaluation include asking people on the satisfaction of their needs, the feel of their existence in a social group, and the question on their purpose in lives and emotions.

Well-Being is also a desirable human state that concerned with the objective and subjective assessment of well-being (La Placa, McNaught, and Knight, 2013). La Placa et al. (2013) explained the definition of well-being as a few domains containing range of social, economic and environmental forces. The domains that provide the resources and the contexts for the generation and maintenance of well-being at all levels of society.

There are literatures on factors associated with the well-being conducted since long time ago including the study of well-being for gerontology. Recently, it is a more significant influence with elderly in particular. Various studies are seeking to increase understanding about factors associated with the welfare of older such as the study of antecedents and outcomes of activity profile (MorrowHowell et al., 2014) and indicators of well-being in later life (Age UK's Index of Well-being in Later Life, 2017). This study has assumed that the level of well-being of elderly influenced by all the factors namely personal factor (Diener, Oishi, \& Lucas, 2003; Green, Iparraguirre, Davidson, \& Zaidi, 2017; Sharifah Rosida Syed Ali, 2012; The International Well Being Group, 2006), social participation, income, neighborhood and living areas.

\section{Personal factor}

It seems that there were studies on the effect of personal factor to the level of well-being among elderly. A previous study from Green, Iparraguirre, Davidson, and Zaidi (2017) refers the main subject 
in personal factor included the living arrangements in old age, family structure and intergenerational support and care and education. The personal factors mentioned had associated with the well-being.

The living arrangement and family structure had influence the well-being among elderly (Agrawal, 2012; Andrade \& De Vos, 2016). The study found that the elderly who are living at least with one child or living alone would disturb their wellness and Chan, Malhotra, Malhotra, and $\varnothing$ stbye (2011) claimed the elderly to have depression symptom. Next, the intergenerational support and care is one of the personal factor that associated to the well-being among elderly (Lin, Chang, and Huang, 2011). This can be supported by Tian (2014) which intergenerational support and care significantly associated with the well-being and mental health among elderly. The study by Lin et al. (2011) taking into account the components in intergenerational support namely living arrangement, intergenerational norms and intergenerational affection. Lastly, education is the personal factor which linked with the well-being (Cachioni et al., 2017). The study claimed that the education attribute for peoples' participation in an activity to acquire the knowledge and form a social connection. Hence, it is very important to investigate the influence of personal factors on the wellbeing among elderly.

\section{Social participation}

The meaning of social participation by World Health Organization (WHO, 2012) as involving or working closely with communities, informing people with information, consulting people with provide feedback, collaborating by partnering with communities in making decision and empowering by ensuring the decision controlled by the communities had influenced their well-being. Meanwhile, Levasseur et al. (2015) claimed social participation is the part of needs of life for every people. Their study on social participation in aging literature had identified the level of the participation which are (1) connecting with people by doing an activity, (2) being close with people, (3) interacting without doing any activity, (4) doing an activity together with other people, (5) lend a hand to other people and (6) contributing to community. Social participation also refers to the social contacts, social activities and voluntary works done by an individual in a community (Hietanen, Aartsen, Kiuru, Lyyra and Read, 2016)

Numerous studies had proven that social participation is one of the crucial determinant to the subjective well-being among elderly. This statement supported by the previous studies where social participation have an influenced to the positive well-being especially for the successful aging (Adams, Leibbrandt, and Moon, 2011). Their findings explain the social context for successful aging including the engagement with people around such as one or more family members, caregivers, neighbours and friends.

Current similar research resulted social participation associated with successful aging as well as the well-being among elderly. Douglas, Georgiou, and Westbrook (2017) used the concept of social contacts, voluntary works and social involvement refers for the social participation as the indicator of successful aging and quality of life. Being involved and interaction with community is the key to increase psychological well-being.

\section{Financial factor}

Financial factor is important in preparation for the old age. Financial factor refers to the financial support, having financial asset and having any debt (Long, 2016). A study by Chan and Fah (2010) 
defines financial factor as financial issues, financial managements, financial knowledge and financial practices.

Financial factor is one of the determinant in subjective well-being among elderly. According to Finance Personal Research Centre (2014) financial situation had an impact to the well-being. The study explained that the elderly with financial difficulties experienced poor well-being compared to the elderly living in good financial situation.

As such in Malaysia, most of the older people facing the financial hardship (Tey et al., 2016). The study had determined that spouse and children financially supported the elderly. Therefore, the concern for the financial factors to the elderly had called out researchers to formulate or create data to make sure they live peacefully without worrying on their financial.

\section{Neighborhood}

A study by Kasim, Ahmad, and Eni (2008) refers the neighborhood to the facilities in the local area with considering the facilities' contribution to sustain the communities. While, Azmi and Karim (2012) explains neighborhood by taking into account the accessibility of the community to basic community facilities namely local shop, school and playground. Therefore, this study defined the neighborhood as refers to the services or facilities provided in a residence.

According to Finance Personal Research Centre (2014), having a good and safe neighborhood, a comfortable house and nice living areas associated to the well-being of an individual in later life. Further, Koh, Leow, and Wong (2015) claims neighborhood safety and accessibility to facilities are important to the elderly. Such evidences created concern for the neighborhood factor to the subjective well-being among elderly.

\section{Level of income}

Income is a fundamental measure for the well-being of an individual (Fleche, Smith, and Sorsa, 2012). A study by Easterlin (2013) finds that people with high level of income living happier than people with low level of income. This fact perhaps suggest that the level of income associated with the subjective well-being among elderly.

An evidence by Gildner et al. (2016) claims that income appears to have influence the wellbeing among elderly. The increasing in income adequacy lead to increase in the well-being. However, a study by Wyshak (2016) finds income is not a major determinant to the subjective well-being among elderly. The analysis in the study on older women shows income and well-being have no significant influence. Hence, this study is important to determine the influenced of the level of income and the subjective well-being among elderly.

In short, various results of previous studies on the factors influenced the well-being among elderly as well as the fact that only a few studies have been conducted in similar areas. However, Malaysia still has no specific index for the well-being among elderly as the indicator to be used for every relevant action related to the well-being. Thus, this study focused on the personal factors, social participation, financial factor, neighborhood and level income as the determinants that affected the well-being among elderly. 


\section{Living Areas}

This study explores the issue on the living areas to the well-being among elderly. Numerous literature on the living areas namely urban area and rural area to the well-being. According to Lawless and Lucas (2011) the living areas refers to the accessibility to local services, social participation, housing cost and environment of the living areas including cleanliness, peacefulness and the safety of the surroundings. All of these claimed by Lawless and Lucas to be associated with the quality of life.

Brereton, Bullock, Clinch, and Scott (2011) investigated that people living in the rural areas more satisfied with their living. Although there were limited of local services, they still enjoy living in peace and quiet rural areas. In Malaysia, ageing in place commonly in rural areas (Hamid, 2015). The study determined that there must be safe living area or neighbourhood and worship places as the fundamental conditions for ageing in place.

Thus, there is still lack study on the living areas to the level of wellbeing on elderly unless the determinants of subjective well-being take into account. This concern to determine the level of being among elderly to the living areas either lining in urban areas or rural areas.

\section{Methodology}

This study used a set of questionnaires using Likert scale to measure the variables of this study. The research instruments comprising three parts, namely part A, B and C. Part A covers the information on the demographic profile of respondent. Meanwhile, part B includes the items on the level of wellbeing of the elderly. Lastly, part $C$ consists on the variables, which are a personal factor, financial factor, neighborhood and the level of income. The items were adopted with modifications to suit the understanding of the information of well-being among elderly.

A number of 466 respondents at the age 50 years old and above were randomly selected from four districts in Selangor which are Petaling, Klang, Sabak Bernam and Hulu Selangor.

Initially, the analysis for this study using descriptive statistic to measure the level of well-being among elderly in Selangor. Next, to assess the extent to which of the factors explained the well-being, the analysis of regression analysis is conducted. Hence, here is the regression model to test the influence of personal factor, social participation, financial factor, neighborhood and the level income to the well-being among elderly:

$$
\begin{aligned}
& \text { WB }=\alpha+\beta_{1} X_{1}+\beta_{2} X_{2}+\beta_{3} X_{3}+\beta_{4} X_{4}+\beta_{5} X_{5}+e \\
& \text { whereby: } \\
& W B=\text { the level of well-being } \\
& \alpha=\text { constant } \\
& \beta_{1}=\text { regression coefficient for } X_{1} \\
& \beta_{2}=\text { regression coefficient for } X_{2} \\
& \beta_{3}=\text { regression coefficient for } X_{3} \\
& \beta_{4}=\text { regression coefficient for } X_{4} \\
& \beta_{5}=\text { regression coefficient for } X_{5} \\
& X_{1}=\text { personal factor } \\
& X_{2}=\text { social participation }
\end{aligned}
$$




$$
\begin{aligned}
& X_{3}=\text { financial factor } \\
& X_{4}=\text { neighbourhood } \\
& X_{5}=\text { the level of income } \\
& e=\text { Error }
\end{aligned}
$$

Lastly, t-test analysis is used to identify the differences between urban areas and rural areas to the level well-being among elderly in Selangor.

\section{Findings}

Descriptive Analysis

Table 1. Demographic Profile

\begin{tabular}{lll}
\hline Profile & Frequency & Percentage (\%) \\
\hline Gender $(n=466)$ & & \\
Male & 187 & 40.1 \\
Female & 279 & 59.9 \\
\hline Age $(n=466)$ & & \\
$50-59$ & 395 & 84.8 \\
$60-69$ & 58 & 12.4 \\
$\geq 70$ & 13 & 2.8 \\
\hline Living areas $(n=466)$ & & \\
Urban & 213 & 45.7 \\
Rural & 253 & 54.3 \\
\hline Income $(n=466)$ & & \\
$\leq 4000$ & 288 & 61.8 \\
$4001-6000$ & 88 & 18.9 \\
$6001-8000$ & 50 & 10.7 \\
$\geq 8001$ & 40 & 8.6 \\
\hline
\end{tabular}

Results of descriptive analysis in table 1 showed the sample of 466 respondents. There were $40.1 \%$ male respondents and $59.9 \%$ female respondents. Over $80 \%$ of the respondents were between the ages of 50 to 59 years old. Whereby about $12.4 \%$ at the age of 60 to 69 years old and $2.8 \%$ of the respondents at the age 70 years old and above. On the other hand, there were $59.9 \%$ of the respondents living in rural areas and $45.7 \%$ of the respondents living in urban areas. The descriptive analysis also revealed that most of the respondents (61.8\%) have earned the income less than RM4000. It is about $18.9 \%$ of the elderly received income between RM4 001 to RM6 000, while it was about $10.7 \%$ of them made in a range of RM 6001 to RM8 000 and it was very least which $8.9 \%$ of the elderly had earned RM 801 and more.

\section{Mean analysis}

To measure the level of well-being among elderly in Selangor, mean analysis was used. 
INTERNATIONAL JOURNAL OF ACADEMIC RESEARCH IN BUSINESS AND SOCIAL SCIENCES

Vol. 9, No. 3, March, 2019, E-ISSN: 2222-6990 @ 2019 HRMARS

Table 2. Level of well-being among elderly in Selangor

\begin{tabular}{cccc}
\hline Variable & Mean & Std. Deviation & Level \\
\hline well-being & 3.2712 & .53001 & moderate \\
\hline
\end{tabular}

Table 2 shows the level of well-being among elderly in Selangor. Based on the scale of measurement, the mean score between 1 to 2 the level is low, the mean score between 2 to 3 the level is moderate and the mean score between 3 to 4 the level is high. Thus, the elderly living in the reasonable level of well-being.

\section{Regression analysis}

Regression analysis was undertaken to measure the independent variables that influence the change in the dependent variable. In this study, multiple linear regression is used to measure the overall influence of the factors to the well-being among elderly in Selangor. All the outliers' cases have been sorted out before the data to be tested for regression analysis.

Table 3. Multiple Regression analysis

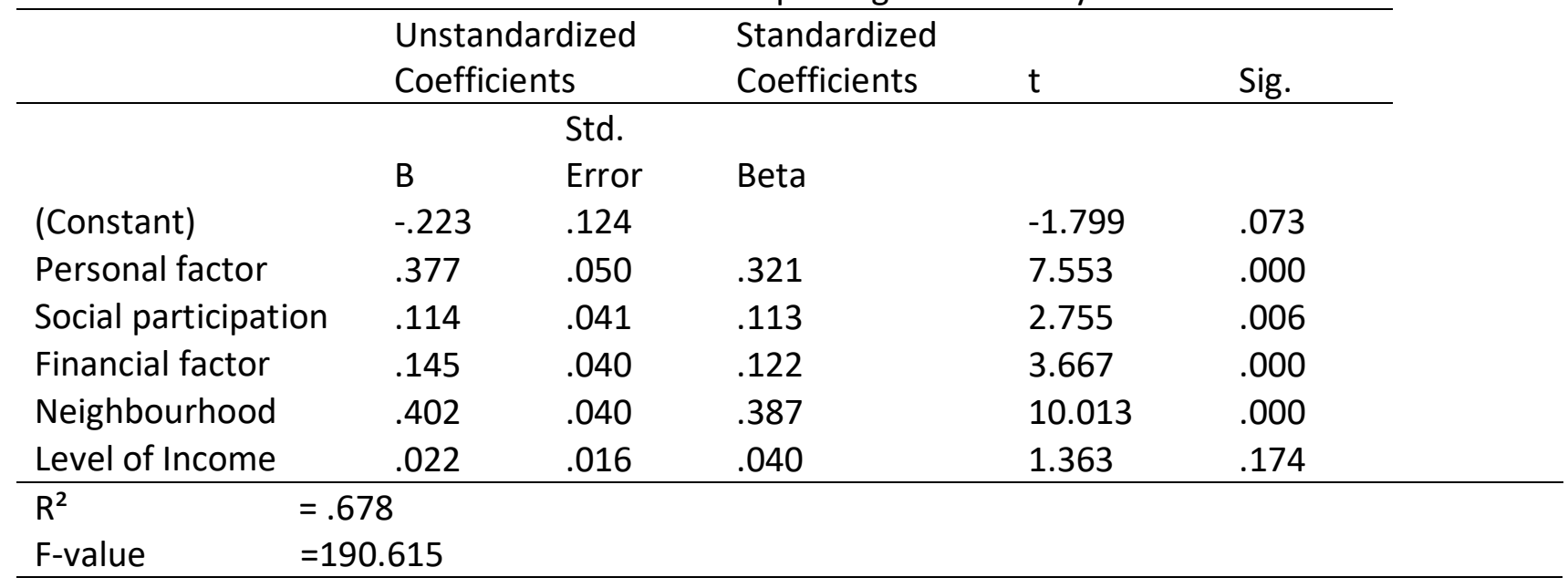

Table 3 shows the result from the regression analysis. The value of R-squared was 0.678 , which indicated that $67.8 \%$ of the variance in the well-being among elderly was explained by personal factor, social participation, financial factor, neighbourhood and the level of income. The result also clearly revealed significant values on the personal factor, social participation, financial factor and neighbourhood. Based on the beta values as the four significant variables, the most influence on the well-being among elderly in Selangor was neighbourhood $(\beta=.387, p=0.000)$, followed by the personal factor $(\beta=0.321, p=0.000)$, financial factor $(\beta=0.122, p=0.000)$ and lastly social participation $(\beta=0.113, p=0.006)$. As for the level of income $(\beta=0.040, p=0.174)$ indicated not significant. Thus, all the factors except for the level of income have influence the well-being of the elderly. 
INTERNATIONAL JOURNAL OF ACADEMIC RESEARCH IN BUSINESS AND SOCIAL SCIENCES

Vol. 9, No. 3, March, 2019, E-ISSN: 222 2-6990 ¿ 2019 HRMARS

\section{T-test analysis}

A t-test analysis was used to access the statistically significant differences between living areas; urban areas and rural areas on the level of well-being among elderly in Selangor.

Table 4. Group Statistics

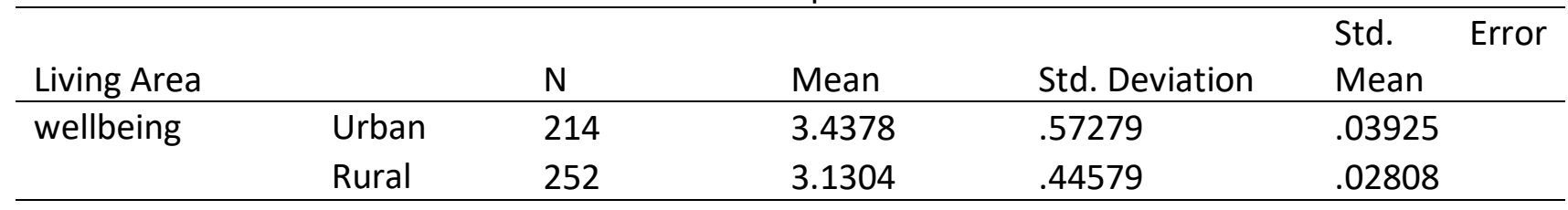

Table 5. Independent Samples Test

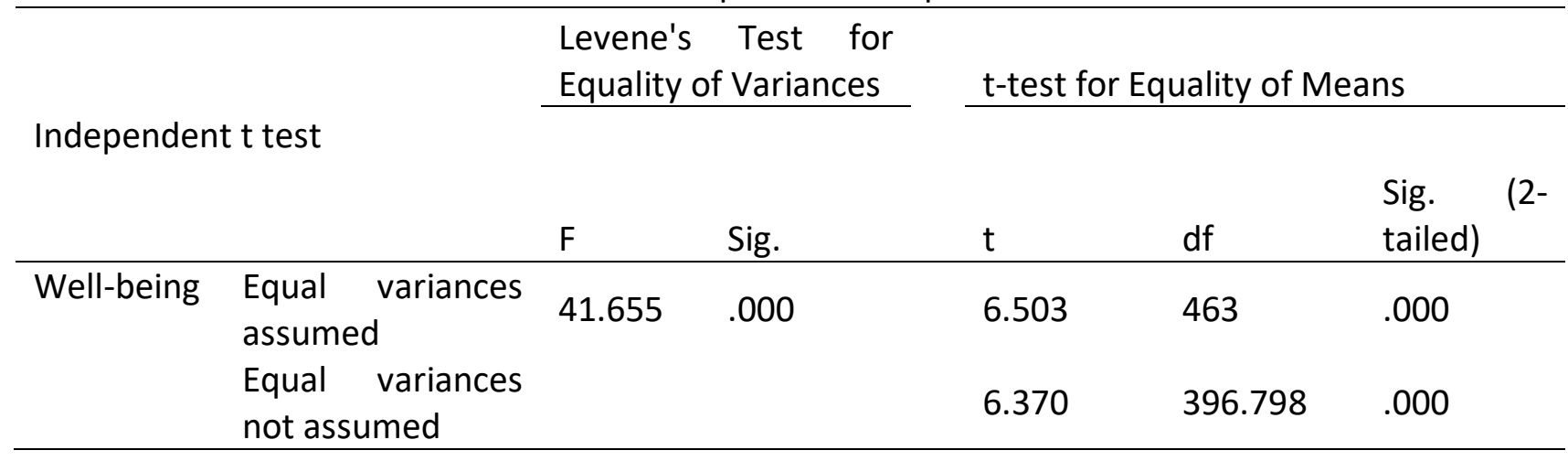

The result shows significant differences between living in urban areas and rural areas, where $p<.05$ (see Table 5). As in table 4, the mean values show that respondents who were living in urban areas are higher than the respondents who are living in rural areas. Thus, the result indicates that elderly who are living in urban areas are more well-being than living in the rural area.

\section{Conclusion}

The personal factor, social participation, financial factor, neighborhood and the level of well-being show significant influences on the well-being among elderly in Selangor. The result shows neighborhood influenced the most on the well-being. It is important to have neighborhood with medical services, transportations and shopping facilities, prior concerned for the well-being among elderly (Green et al., 2017). Moreover, Hamid (2015) claims the fundamental conditions for ageing in place are having security in neighborhood and the existence of worship places. Hence, it is essential to have services and facilities in the neighborhood for the elderly.

Besides, this study found that there is no significant influence of the level of income on the wellbeing among elderly in Selangor. As stated by Easterlin (2013) the increasing in the level of income does not increase the well-being. However, elderly are commonly have poor health and vulnerable which they need adequate income to pay for their health services (Wyshak, 2016). Wyshak (2016) stressed that better health strongly associated with higher level of income. 
However, income appears to influence the well-being in the long term (Diener and Biswas-Diener, 2002). According to Easterlin (2013), the well-being does not increase as income goes up. However, as an elderly are vulnerable and commonly have poor health. Income inequality affect their wellbeing as they have inadequate income to pay for their health services. Instead, better health associated with higher income (Wyshak, 2016).

On the other hand, the level of well-being of the elderly who are living in urban areas higher than living in urban areas. The result supported by numerous researches, claimed that the elderly living in rural areas experienced the lower level of well-being than living in urban areas. One of the reason because of the rural commonly have limited access to facilities and services compared to urban areas (Baernholdt, Yan, Hinton, Rose and Mattos, 2013; Requena, 2016).

As a conclusion, this paper provides evidence and information regarding the influences of subjective well-being and income to the level well-being among elderly in Selangor. Therefore, it might suggest that elderly must be provided with their needs to increase their level of well-being.

\section{Acknowledgement}

Funded under Research Grant by MOHE, FRGS (2016-0083-106-02)

\section{Corresponding Author}

Ramlee Ismail,

Faculty of Management and Economic, Universiti Pendidikan Sultan Idris, 35900 Tanjong Malim,

Perak, Malaysia

Email: ramlee@fpe.upsi.edu.my

\section{References}

Adams, K. B., Leibbrandt, S., \& Moon, H. (2011). A critical review of the literature on social and leisure activity and wellbeing in later life. Ageing and Society, 31(4), 683-712. https://doi.org/10.1017/S0144686X10001091

Agrawal, S. (2012). EFFECT OF LIVING ARRANGEMENT ON THE HEALTH STATUS OF ELDERLY IN INDIA. Asian Population Studies, 8(1), 87-101. https://doi.org/10.1080/17441730.2012.646842

Andrade, F. C., \& De Vos, S. (2016). An analysis of living arrangements among elderly women in Brazil. Encontro Da Associacao Brasileira de Estudos Populacionais, 14(8).

Azmi, D. I., \& Karim, H. A. (2012). Implications of Walkability Towards Promoting Sustainable Urban Neighbourhood. Procedia - Social and Behavioral Sciences, 50(July), 204-213. https://doi.org/10.1016/j.sbspro.2012.08.028

Baernholdt, M., Yan, G., Hinton, I., Rose, K., \& Mattos, M. (2013). Quality of Life in Rural and Urban Adults 65 Years and Older: Findings From the National Health and Nutrition Examination Survey. Journal of Rural Health, 28(4), 339-347. https://doi.org/10.1111/j.17480361.2011.00403.x.Quality 
INTERNATIONAL JOURNAL OF ACADEMIC RESEARCH IN BUSINESS AND SOCIAL SCIENCES

Vol. 9, No. 3, March, 2019, E-ISSN: 222 2-6990 @ 2019 HRMARS

Bahagian Pasca Perkhidmatan. (2015). Takrifan Warga Tua di Malaysia.

Brereton, F., Bullock, C., Clinch, J. P., \& Scott, M. (2011). Rural change and individual well-being. European Urban and Regional Studies, 18(2), 203-227. https://doi.org/10.1177/0969776411399346

Cachioni, M., Delfino, L. L., Yassuda, M. S., Batistoni, S. S. T., Melo, R. C. de, \& Domingues, M. A. R. da C. (2017). Subjective and psychological well-being among elderly participants of a University of the Third Age. Revista Brasileira de Geriatria E Gerontologia, 20(3), 340-351. https://doi.org/10.1590/1981-22562017020.160179

Chan, A., Malhotra, C., Malhotra, R., \& Østbye, T. (2011). Living arrangements, social networks and depressive symptoms among older men and women in Singapore. International Journal of Geriatric Psychiatry, 26Chan, A. (6), 630-639. https://doi.org/10.1002/gps.2574

Chan, B., \& Fah, Y. (2010). Financial Wellbeing of Older Peninsular Malaysians : A Gender Comparison. Asian Social Science, 6(3), 58-71. https://doi.org/10.5539/ass.v6n3p58

Diener, E., Oishi, S., \& Lucas, R. E. (2003). Personality, Culture, and Subjective Well-being: Emotional and Cognitive Evaluations of Life. Annual Review of Psychology. Department of Psychology, University of Illinois, Champaign, IL 61820, United States. https://doi.org/10.1146/annurev.psych.54.101601.145056

Diener, E., Oishi, S., \& Lucas, R. E. (2015). National accounts of subjective well-being. American Psychologist, 70(3), 234-242. https://doi.org/10.1037/a0038899

Douglas, H., Georgiou, A., \& Westbrook, J. (2017). Social participation as an indicator of successful aging: An overview of concepts and their associations with health. Australian Health Review, 41(4), 455-462. https://doi.org/10.1071/AH16038

Easterlin, R. A. (2013). HAPPINESS, GROWTH, AND PUBLIC POLICY†. Economic Inquiry, 51(1), 1-15. https://doi.org/10.1111/j.1465-7295.2012.00505.x

EPU. (2013). The malaysian well-being report 2013, (December).

Finance Personal Research Centre. (2014). Financial wellbeing in later life.

Fleche, S., Smith, C., \& Sorsa, P. (2012). Exploring Determinants of Subjective Wellbeing in OECD Countries EVIDENCE FROM THE WORLD VALUE SURVEY. Working Papers, OECD Statistics, (2012). https://doi.org/10.1787/5kg0k6zlcm5k-en

Gildner, T. E., Liebert, M. A., Capistrant, B. D., D’Este, C., Snodgrass, J. J., \& Kowal, P. (2016). Perceived Income Adequacy and Well-being Among Older Adults in Six Low- and Middle-Income Countries. The Journals of Gerontology Series B: Psychological Sciences and Social Sciences, O(0), gbw145. https://doi.org/10.1093/geronb/gbw145

Green, M., Iparraguirre, J., Davidson, S., \& Zaidi, A. (2017). A summary of Age UK's Index of Wellbeing in Later Life, 1-16. Retrieved http://www.ageuk.org.uk/search1/?keyword=index+of+wellbeing\&nation=ageuk_en-GB 
INTERNATIONAL JOURNAL OF ACADEMIC RESEARCH IN BUSINESS AND SOCIAL SCIENCES

Vol. 9, No. 3, March, 2019, E-ISSN: 222 2-6990 @ 2019 HRMARS

Hamid, T. (2015). Population Ageing in Malaysia. POPULATION AGEING IN MALAYSIA A Mosaic of Issues, Challenges and Prospects, 92.

HIETANEN, H., AARTSEN, M., KIURU, N., LYYRA, T.-M., \& READ, S. (2016). Social engagement from childhood to middle age and the effect of childhood socio-economic status on middle age social engagement: results from the National Child Development study. Ageing and Society, 36(3), 482-507. https://doi.org/10.1017/S0144686X1400124X

Kasim, R., Ahmad, A. R., \& Eni, S. (2008). the Neighbourhood Facilities and the Sustainable Communities Agenda : an Overview ., (June 2014).

Koh, P. P., Leow, B. W., \& Wong, Y. D. (2015). Mobility of the elderly in densely populated neighbourhoods in Singapore. Sustainable Cities and Society, 14, 126-132.

La Placa, V., McNaught, A., \& Knight, A. (2013). Discourse on wellbeing in research and practice. International Journal of Wellbeing, 3, 116-125. https://doi.org/10.5502/ijw.v3i1.7

Lawless, N. M., \& Lucas, R. E. (2011). Predictors of Regional Well-Being: A County Level Analysis. Social Indicators Research, 101(3), 341-357. Retrieved from http://www.jstor.org/stable/41476450

Levasseur, M., Généreux, M., Bruneau, J.-F., Vanasse, A., Chabot, É., Beaulac, C., \& Bédard, M.-M. (2015). Importance of proximity to resources, social support, transportation and neighborhood security for mobility and social participation in older adults: results from a scoping study. BMC Public Health, 15(1), 503. https://doi.org/10.1186/s12889-015-1824-0

Lin, J.-P., Chang, T.-F., \& Huang, C.-H. (2011). Intergenerational relations and life satisfaction among older women in Taiwan. International Journal of Social Welfare, 20, S47-S58. https://doi.org/10.1111/j.1468-2397.2011.00813.x

Long, G. T. (2016). Gender Differences in Financial Sources and Perceived Financial Satisfaction Among Older People in Vietnam, 18(2), 36-58.

Morrow-Howell, N., Putnam, M., Lee, Y. S., Greenfield, J. C., Inoue, M., \& Chen, H. (2014). An Investigation of Activity Profiles of Older Adults. The Journals of Gerontology Series B: Psychological Sciences and Social Sciences, 699(5), 809-821. https://doi.org/10.1093/geronb/gbu002

Requena, F. (2016). Rural-Urban Living and Level of Economic Development as Factors in Subjective Well-Being. Social Indicators Research, 128(2), 693-708. https://doi.org/10.1007/s11205-0151051-1

Sarracino, F. (2010). Social capital and subjective well-being trends: Comparing 11 western European countries. Journal of Behavioral and Experimental Economics (Formerly The Journal of SocioEconomics), 39(4), 482-517. Retrieved from http://econpapers.repec.org/RePEc:eee:soceco:v:39:y:2010:i:4:p:482-517

Tey, N. P., Siraj, S. B., Kamaruzzaman, S. B. B., Chin, A. V., Tan, M. P., Sinnappan, G. S., \& M??ller, A. M. (2016). Aging in multi-ethnic Malaysia. Gerontologist, 56(4), 603-609. https://doi.org/10.1093/geront/gnv153 
INTERNATIONAL JOURNAL OF ACADEMIC RESEARCH IN BUSINESS AND SOCIAL SCIENCES

Vol. 9, No. 3, March, 2019, E-ISSN: 222 2-6990 ¿ 2019 HRMARS

The International Well Being Group. (2006). Personal Wellbeing Index - Adult ( English ). October. Retrieved from http://www.google.be/url?sa=t\&rct=j\&q=personal wellbeing index manual\&source=web\&cd=2\&ved=0CDsQFjAB\&url=http://www.deakin.edu.au/research/acqol/ instruments/wellbeing-index/pwi-adult-

english.pdf\&ei=WmcGUeDIBPGTOQXsy4CoDQ\&usg=AFQjCNG_-FHEaODIDyvTOJANyExGKJ9

Tian, Q. (2014). Intergeneration social support affects the subjective well-being of the elderly: Mediator roles of self-esteem and loneliness. Journal of Health Psychology, 21(6), 1137-1144. https://doi.org/10.1177/1359105314547245

United Nations. (1983). Vienna International Plan of Action on Aging. World Assembly on Aging, 150. https://doi.org/10.1134/S2079057014030060

World Health Organization. (2012). Social determinants of health: Social participation, 1-3. Retrieved from

http://www.who.int/social_determinants/thecommission/countrywork/within/socialparticipat ion/en/index.html

Wyshak, G. (2016). Income and Subjective Well-Being: New Insights from Relatively Healthy American Women, Ages 49-79. PLOS ONE, 11(2), 1-16. https://doi.org/10.1371/journal.pone.0146303 